\title{
Determinant Factors of The Effectiveness Learning Process and Learning Output of Equivalent Education
}

\author{
Joko Sutarto \\ Department of Nonformal Education \\ Universitas Negeri Semarang \\ Gedung A Kampus Sekaran Gunungpati Semarang 50229, Indonesia \\ jokotarto@mail.unnes.ac.id
}

\begin{abstract}
Recently, The effectiveness learning of equivalent education is influenced by many kinds of factors, those are, tutor motivation, tutor commitment, leadership, means and infrastructure, finance, and working environment. This study aim to analyze the influence of tutor commitment factor, leadership, work environment condition to the effectiveness of learning process; and the influence of the effectiveness of learning process toward learning output of equivalent education. Sample to be studies wethe 204 tutors of Sanggar Kegiatan Belajar (SKB) equivalent education in Cenral Java. Sampling technique is "area probability random sampling". Data collecting is done by graded scale questionnaire. Data analyzing done by linear regression analysis. This study found that: (a) tutor commitment factor with contributed a direct influence to the effectiveness learning process with a percentage of $18,49 \%$. (b)SKB leadership factors with contributed a direct influence to the effectiveness learning process with a percentage of $44,89 \%$; (c)work environment condition with contributed a direct influence to the effectiveness learning process with a percentage 26,57\%; (e) design of instructional plans impact on the participants outputs was $29,47 \%$, and (f) implementation of instructional impact on the participants outputs was $40,96 \%$. Implication of study outcome intended to improve the effectiveness of learning. It is done by enhancement of tutor commitment and creating work environment condition.
\end{abstract}

Keywords - learning effectiveness, commitment, leadership, and work environment Introduction

\section{INTRODUCTION}

The effectiveness learning of equivalent education is a reflection of the quality of non-formal education as a whole, which is in its implementation is determined by various factors such as tutor motivation, tutor commitment, leadership, means and infrastructure, finance, and working environment. Tutor educational equality is one of the aspects in learning process which has multiple roles, not only as a teacher who initiated the transfer of knowledge, but also as a mentor who encourages potential, develops alternative, and mobilizes students in developing their learning. It is emphasized if the tutor has a high commitment, it can be expected learners will achieve satisfactory academic achievement. The effectiveness learning is inseparable from management system developed, so that the leadership factor and working environment developed is very important and decisive role. subordinates involvement in the dynamic of organization is participation in the decision making process based on the authority granted by According to A Fleismen [1], leadership is an attempt to influence people between individuals, through the communication process to achieve something or multiple destinations. Brookover et al [2] suggested that a working climate of the conductivity of study groups influence the attitudes and actions of all community learning groups, particularly in the academic achievement of students. More pointedly, Purkey and Smith [3] also state that the students' academic achievement is influenced very strongly by the psychological atmosphere or climate study group work. Further Hughes [4] asserts that any educational institution such as study groups has the character of working environment, which will affect the success of the process of learning activities.

Result of the previous research showed that working behavior of an organization is determined by the working environment within the organization [2][3][4]. Various attempts have been made to optimize the learning process of non-formal education through courses to improve the competence of the tutor, introduction the new methods of learning, as well as the repair and improvement of educational facilities and infrastructure, but the programs implemented have not touched the root of the problem. The scope of this learning problems related to the learning effectiveness of the educational equality with the consideration that the effectiveness of learning can be realized by utilizing the potential and energy that owned unit of the equality of education providers In theory, the various factors that influence the effectiveness of learning as a factor of knowledge, skills, working motivation, leadership, work climate, finance, and learning infrastructure. This research did not reveal all of these factors, but limited to tutor commitment, SKB leadership, and the environment of the working climate is predicted to affect the effectiveness of learning, and impact on learning outcomes. The aim of this research is to analyze the direct affects: (a) factors tutor commitment to the effectiveness of learning; (b) factors of SKB leadership to the effectiveness of learning; (c) environment factors work against the effectiveness of learning; (d) the effectiveness of the learning plan on learning outcomes; and (e) the effectiveness of learning implementation toward learning outcomes. 


\section{LITERATURE REVIEW}

Various theories, concepts, ideas which serve as a reference and as well as theoretical base in solving research problems formulated above explained in the following description. Scheerens and Creemers [5] developed a model that links several levels of the education system that contributes to the effectiveness of learning. The model was demonstrated that factors in the educational unit level and grade level affect the effectiveness of the learning and achievement of learning outcomes. Models that have been tested show that ultimately focused on learning behavior and educational outcomes. The diagram below shows the multi-level contextual relationship to improve the quality of the learning process.

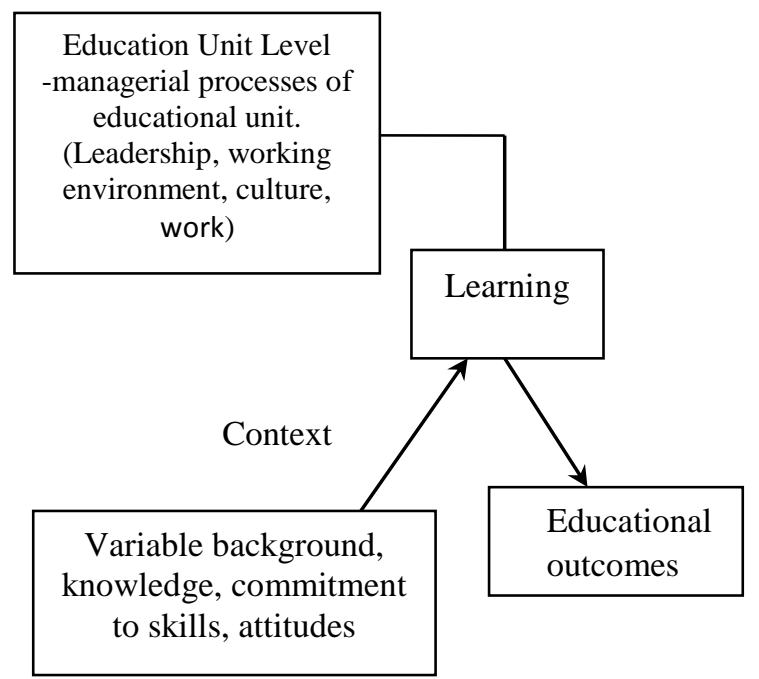

Fig. 1. Multilevel Contextual Model for Learning Effectiveness (Source: Scheerens \& Creemers, 1989)

Successful implementation of an equal educational learning strategy will depend on tutor competence in using methods, techniques, and tactics of learning. It is believed, each tutor will have the experience, knowledge, ability, skill, and even a different view in implementing the learning. Thus the learning effectiveness is determined by the commitment of tutors. The learning process is designed to provide new knowledge, new skills, by encouraging individuals to achieve more than what he knows. Tutor role as an educators of equal education more creating an atmosphere, to give meaning to the generalizations [6]. A number of factors can affect the effectiveness of learning investigate from educators factors, those are formative teacher experience, teacher training experience, and teacher properties [7]. Teacher formative experience, include sex as well as all of their life experiences into their social background. Teacher training experience, including experiences related activity and educational backgrounds, such as professional training experience, level of education, experience positions. Teacher properties is everything related to properties owned, such as attitudes toward the profession, attitude towards learners, ability or knowledge in the management of learning and assessment of learning and mastery learning materials. Increasing commitment does not always lead to behavioral change, but a positive relationship between these two variables is shown in research of Carwright and Stanford in Green [8]. In general commitment is individual psychological bond to the organizations that include a sense of involvement in a work, loyalty, and trust in the values of the organization [9]. Another look at the commitment formulated by Meyer and Allen Chited Shirbagi [10], by dividing the commitments into affective commitment, continuance commitment, and normative commitment. Affective commitment is individual's emotion attachment to the organization, continuance commitment refers to the individual's recognition to the benefits as a member of the organization, particularly in terms of cost, and normative commitment refers to the sense of individual obligation to the organization.

By systematically utilize the function of leadership, planning and using the right approach it is possible to boost the achievement of the effectiveness learning of educational equality in the future. It is based on the fact that availability of funds, infrastructure, facilities, and other educational instruments may not be able to be utilized to the maximum, efficient, and accountable without any strong of leadership, or a leader who is able to activate all of educational component. With the existence of the leadership that is able to influence and mobilize all of education resources (human and non-human resources) is predicted can spur and simultaneously trigger the attainment of quality of education learning equality. In other words, the availability of educational resources may not be able to be utilized optimally without any leader who is able to motivate, here it is the importance of educational leadership in achieving the quality of education. SKB chief as a unit leader is an educational leader at the operational level at the forefront coordinating efforts to improve the quality of learning process. Sociological studies about the effectiveness of educational unit indicates that the leadership of chairman of the organizing educational unit plays a very important role and vital. Research conducted by Wohlstetter, Priscilla [11] concluded that the attention of the leader of the educational unit was higher against quality couching, its commendable behavior, and the attitude of responsiveness in raising issues addressed significantly decrease the frequency of behavior is not commendable learner and otherwise to improve the life of the unit education.

Conceptually, the environment and working climate in the educational unit is defined as a set of attributes that gives color or character, spirit, ethos, spiritual atmosphere of any educational institution [12]. Operationally, as well as understanding climate on weather, environment work climate in education units are measured using the average of the community perception of education units on aspects that determine the work environment. Research on educational environment shows that the atmosphere as well as other factors such as curriculum, facilities, and school leadership, learning environment in the classroom and school have an important role in the formation of effective educational unit. For two decades, the learning environment is considered as one of the determinant factors of the effectiveness educational unit [13]. Fisher and Fraser [12] better process learning. Freiberg [14] asserts that a healthy working environment contributes against the effectiveness of learning process significantly. He argues that the creation of a conducive environment makes all members perform their duties and their role optimally. 
Sweetland and Hoy [15] stated that the working climate of educational unit in which educator empowerment a priority is very essential toward the effectiveness of learning in the estuary affects learner's achievements overall.

\section{METHOD}

This research aimed to examine the affect of tutor commitment variable, SKB leadership, and working climate against of the effectiveness learning of equality educational; all at once is investigated the influence of the learning plan, and implementation of learning toward learner's outcomes. This research is included a survey research with subtracting sample of population that using questionnaires an instrument to collect primary data. For the design of the study determined using linear regression analysis.

Variables revealed in this research include the independent variable, and the dependent variable: (a) Independent variable is the cause of the suspected or variable occurs first. The independent variable $(X=X I, X 2$, and $X 3)$ are various factors that consists of three variables: the commitment tutor (XI), the leadership of the head of LCS (X2), and the work climate (X3); and (b ) the dependent variable (the dependent variable), the effectiveness of educational learning equivalence $(\mathrm{Y})$. The research sample is a group of members that are part of the population, and has the characteristics of the population. As the samples was determined at 204 people of the total population of 432 people with engineering tutor equal education "Area proportional random sampling".

The effectiveness of learning measured from the behaviors tutor in the planning and implementation of learning in the manner of indicator of using methods, learning materials and media, communicate with learner, demonstrating their treasure of learning methods, encouraging and directing the involvement of learners, develop a positive attitude, being aboveboard to the learners, featuring activities in learning, and asses the learning process and supervise the activities of learners. Commitment tutor refers theory developed by Mowday, Strees and Porter (in Mguqulwa, 2008) consists of three indicators that can foster commitment, namely: (1) a strong believe and acceptance of the goals and values to the organization; (2) a willingness to exert the great effort on behalf of the organization; (3) a strong desire to maintain membership in the organization. The indicator used to measure leadership LCS refers to a theory developed by Lipham, namely: (a) have a vision; (b) have the assurance that study group is to study the learners; (c) respect of human resources; (d) communication skills and listening; (e) act proactively; (f) the development of openness; and $(\mathrm{g})$ are willing to face the risk [16].The work climate indicators is based on the theory Caldweel and Spinks [17], which contains: their work rules , upholds norms and customs in force, the creation of a family atmosphere, atmosphere / climate work to support the work , created transparency in decision-making, the intimate relationship between people involved, the study supports the activities and presence of adequate incentives for the personnel involved .

Instrument used for data collection was a questionnaire. To calculate the validity of the instrument used by the Pearson product moment formula calculations using SPSS / PC + release 10.0 [18]. Data were analyzed using linear regression analysis.

\section{RESULT}

\section{A. Result of Research}

The results of calculation parameters on the significance of the independent variables affect the dependent variable (the learning effectiveness) are presented in the summary table below:

TABLE I. Summary Of The Results Of The CAlCulation Of The INDEPENDENT VARIABLE PARAMETER SIGNIFICANCE INFLUENCING THE EFFECTIVENESS OF LEARNING

\begin{tabular}{|l|c|c|l|}
\hline \multicolumn{1}{|c|}{ Exogenous Construct } & $\begin{array}{c}\text { Skor } \\
\mathbf{T}\end{array}$ & $\begin{array}{c}\boldsymbol{\alpha} \\
\mathbf{5 \%}\end{array}$ & Note \\
\hline Tutor Commitment & 3,41 & 1,96 & Significant \\
SKB chief Leadership & 4,17 & 1,96 & Significant \\
Work Climate & 3,49 & 1,96 & Significant \\
\hline
\end{tabular}

Results of the analysis of the effect of variable tutor commitment, SKB chief leadership, and the work climate, the effectiveness of learning (measured on the effectiveness in planning, implementing, supervising and assessing the learning process), presented in the summary table below:

TABLE II. SUMMARY OF RESULTS OF REGRESSION ANALYSIS OF FACTORS INFLUENCE COMMITMENT TUTOR, SKB CHIEF LEADERSHIP, WORK CLIMATE OF THE EFFECTIVENESS OF LEARNING

\begin{tabular}{|c|c|c|c|c|c|c|}
\hline \multirow[b]{2}{*}{$\begin{array}{c}\text { Exogenous } \\
\text { Construct }\end{array}$} & $\begin{array}{c}\text { Endog } \\
\text { enous } \\
\text { Constr } \\
\text { uct }\end{array}$ & \multirow[b]{2}{*}{$\mathbf{T}$} & \multirow{2}{*}{$\begin{array}{c}\alpha \\
0,05\end{array}$} & \multirow[b]{2}{*}{$\begin{array}{l}\text { Direct } \\
\text { Effect }\end{array}$} & \multirow[b]{2}{*}{$\begin{array}{c}\text { In } \\
\text { direct } \\
\text { Effects }\end{array}$} & \multirow[b]{2}{*}{$\begin{array}{l}\text { Total } \\
\text { Effect }\end{array}$} \\
\hline & $\begin{array}{c}\text { Effec } \\
\text { tiven } \\
\text { ess } \\
\text { of } \\
\text { Lear } \\
\text { ning }\end{array}$ & & & & & \\
\hline $\begin{array}{l}\text { Tutor } \\
\text { Commitment }\end{array}$ & 0,43 & 3,41 & 1,96 & 18,49 & 6,35 & 24,84 \\
\hline $\begin{array}{l}\text { SKB Chief } \\
\text { Leadership }\end{array}$ & 0,67 & 4,17 & 1,96 & 44,89 & 7,50 & 52,39 \\
\hline $\begin{array}{l}\text { Working } \\
\text { Atmosphere }\end{array}$ & 0,49 & 3,49 & 1,96 & 26,57 & 6,69 & 33,26 \\
\hline
\end{tabular}


TABLE III. SUMMARY OF REGRESSION ANALYSIS OF FACTORS INFLUENCE THE LEARNING PLAN, ANDA IMPLEMENTATION OF LEARNING TO ACQUISITION OF LEARNING OUTCOMES

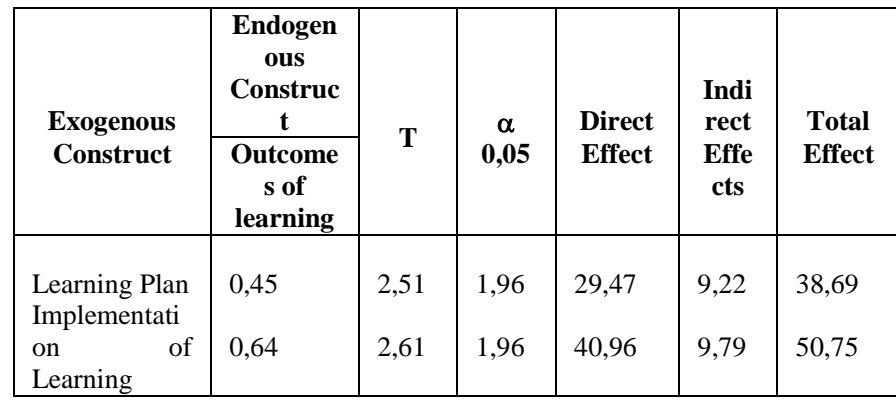

Based on the scores are presented in the table can be explained as follows:

- The major variable path coefficient commitment to learning effectiveness was 0.43 with a positive direction, which means that the stronger the commitment which tutor have, the stronger the learning effectiveness. Large direct influence factors on the effectiveness of learning tutor commitment of (0.43) 2, or 0.1849 . Thus it can be seen that $18.49 \%$ effectiveness of study due to factors inherent in a commitment to tutor concerned. While the magnitude of the variable scores indirect influence on the effectiveness of learning tutor commitment because of its relationship with the leadership and working climate factor is $6.35 \%$. Means in total (total effect) influence factors tutor commitment, leadership, and work on the effectiveness of the learning climate $24.84 \%$.

- Great leadership path coefficients of the variables of the effectiveness of learning is 0.67 with a positive direction, which means that the stronger leadership, the stronger effectiveness of study designed by the tutor. The magnitude of the direct influence of the effectiveness of instructional leadership variables of (0.67) 2 , or 0.4489 . Thus it can be seen that the leadership factor of $44.89 \%$ direct impact on the effectiveness of learning. While the magnitude of score indirect influence on the effectiveness of instructional leadership variable because of its relationship with the variable commitment tutor, and $7.50 \%$ working climate. This means that in total (total effect) variables influence the leadership, commitment tutor, and working climate of the effectiveness of learning is $52.39 \%$.

- The path coefficients of the major climate variables work against the effectiveness of study is 0.49 with a positive direction, which means that the better the working environment is developed, the more effective the learning process carried out by the tutor. The magnitude of the effect of climate variables work directly on the effectiveness of learning is equal to (0.49) 2 , or 0.2657 . Thus it can be seen that $26.57 \%$ of the changes that occur in the learning effectiveness is directly due to the favorable work climate. While the magnitude of score indirect influence variable climate atmosphere work on the effectiveness of learning because of its relationship with the variable tutor commitment and leadership variables was $6.69 \%$. This means that in total (total effect) influence the working climate variables, tutors commitment and leadership on the effectiveness of learning is $33.26 \%$.

- Factor learning plan gives direct effect (direct effect) to the acquisition of learning outcomes residents learn by $29.47 \%$, while the direct effect (direct effect) the implementation of learning to the acquisition of learning outcomes residents learn by $40.96 \%$. Thus the magnitude of the effect of the implementation of learning to the acquisition of learning outcomes learners showed a higher score than the magnitude of the effect of the acquisition of the learning plan learning outcomes residents learn with a ratio of $40.96 \%: 29.47 \%$.

For more details, diagrams path variable effect tutor commitment, SKB leadership, and the working environment of the effectiveness of learning can be explained in the following stripe diagram.

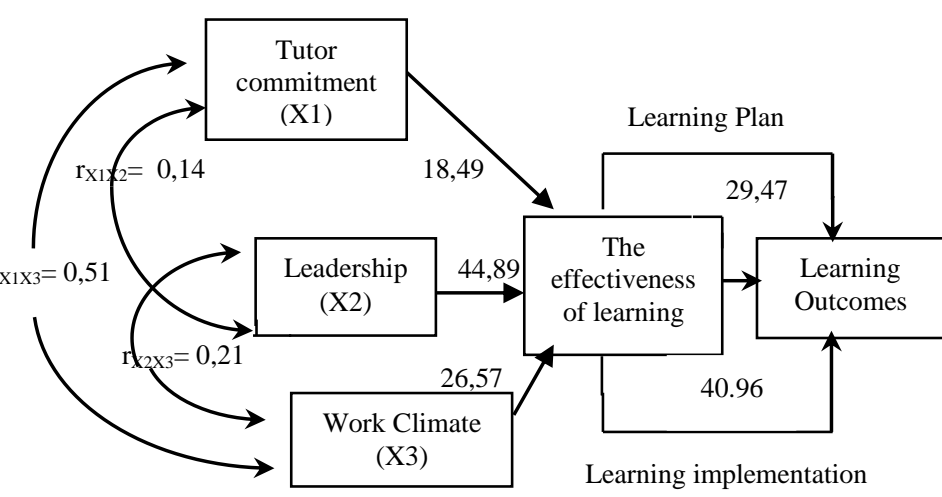

Fig. 2. Factors Influence Tutor Commitment, Leadershipand Working Climate of the Effectiveness of Learning

\section{DISCUSSION}

Based on the path diagram tutor factors influence commitment, leadership LCS, and the work atmosphere study of the effectiveness learning above can be addressed:

Variable commitment to have a significant influence on the effectiveness of learning, with the amount of direct influence $18.49 \%$. The study's findings are in line with the concept expressed Gibson [1], which explicitly explain their real influence of individual variables (knowledge/ capability) on behavior and work performance of the duties of the individual concerned. Research conducted Borich [19] found an effect of the characteristics (personality and attitude) to the quality of learning and educational outcomes in the form of products and the enhancement of skills of learners. Commitment is one of the predisposing variables (individual characteristics of the sub-variables) that influence a person's behavior, there are other variables sub (sub psychological variables) that a person's attitude. Commitments related to the behavior, attitude is composed of three components of understanding, compassion, and behavior. As noted Robbin [20] of commitment can be seen as a predisposition to react in a way that is favorable or 
unfavorable to objects, people, concepts, or whatever, that attitude associated with a person's behavior. The results of the study support previous research from Wadhwa [21] which states the commitment, in this case the supervisor as a determinant in the implementation of effective academic supervision. SKB chief leadership variables have a significant influence on the effectiveness of learning, with the amount of direct influence $44.89 \%$. The findings of this study support previous studies that found no relationship between leadership styles displayed by the work behavior [22]. Variable working climate atmosphere provides a very significant influence on the effectiveness of learning, with the amount of influence $44.89 \%$. Several studies and views that support the results of this research include: Research Steffen [23] of the climatic influences of work organization as a determinant of quality of service, independent variables: the commitment of staff, work rules, job descriptions, and labor relations, the research concluded that the commitment of the staff, work rules, clarification of the task, and the working relationship marred openness is positively correlated to the dependent variable, namely the quality of service; The other view expressed Rodwell, et.al, [24] about the practice of organizational communication in the context of human resource management, climate variables work, communication work, work rules, affect the behavior of labor.

\section{CONCLUSION AND SUGGESTION}

\section{A. Conclusion}

- The variable tutor's commitment to give effect to the effectiveness of learning, with the amount of direct influence of $18.49 \%$; the indirect effect of $6.35 \%$; and the effect of a total of $24.84 \%$.

- The variable of leadership gives the influence toward the effectiveness of learning, with the amount of direct influence of $44.89 \%$.

- The working atmosphere variables impact the effectiveness of study, with the amount of direct influence of $26.57 \%$; the indirect effect of $6.69 \%$; and the effect of a total of $33.26 \%$.

- Variable lesson plans directly affect learning outcomes learners' acquisition of $29.47 \%$, the indirect effect of $9.92 \%$; and the effect of a total of $38.69 \%$. While the direct effect of the implementation of learning to the acquisition of learning outcomes residents learn by $40.96 \%$, the indirect effect of $9.79 \%$; and the effect of a total of $50.57 \%$

\section{B. Suggestion}

- Enhancing the effectiveness of equality of educational learning is done through an increase in the variable having a low coefficient of which is still, primarily increased commitments tutor, and increased work motivation tutor.
- Training teaching models, learning curriculum and instructional media based on the philosophy, principles, and approaches of non-formal education (andragogy) needs to be given to the tutor to improve his behavior effectiveness in learning.

- To improve the working climate conducive for tutors gain comfort in the work, and these conditions will provide positive support for the tutor to actualize himself. Strengthening work climate that is believed to support the quality of the education process of equality is their work rules referenced in the learning process, the norms are upheld, development attitude of openness between the organizer and tutor .

- There should be further research to increase or develop any other variables that have not been revealed in this study. However, further research will be able to add insight into the effectiveness of equality of educational learning that continuously require improvement towards more innovative.

\section{REFERENCES}

[1] Gibson, James L dan Ivancevich, Organizations. Ten Edition. New York : Richard D. Irwin, 2000.

[2] Brookover, W. B., Schweitzer, J. H., Schneider, J. M., Beady, C. H., Flood, P. K., \& Weisenbaker, J. M, "Elementary school social climate and school achievement,".American Educational Research Journal, vol 15, pp. 301-318, 1978.

[3] Purkey, S. C., \& Smith, M. S, Too soon to cheer? Synthesis of research on effective schools, Educational Leadership(40), 64-69, 1985.

[4] Hughes, P. W, Teachers' professional development, Melbourne, Victoria: Australian Council for Educational Research, 1991.

[5] Scheerens, J \& Creemers B.P.M, Conseptualizing school Effectiveness. International Journal of Educational Research, 13 (7), pp. 691-706, 1989.

[6] Lunandi A.G, Andragogy., Jakarta : PT Gramedia, 1982.

[7] Dunkin, Michael J, The International of Teaching and Teacher Education, England : Pengamoon Press, Headington Hill Hall, 1974.

[8] Green, Lawrence, Health Education Planning, A Diagnotic Approach, California : Myfield Publishing Company, 1980.

[9] Mgqulwa, N, "The Relationship Between Organisational Commitment and Work Performance in an Agricultural Company, Tesis, Preller St, Pretoria: University of South Africa. 2008

[10] Shirbagi, N, "Exploring Organizational Commitment and Leadership Frames within Indian and Iranian Higher Education Institutions". Bulletin of Education \& Research, Volume 29, No, 1, pp. 17-32, 2007.

[11] Wohlstetter, Priscilla, Ani N. Van Kirk, Peter J. Roberston, dan Susan A Mohrman, Organizing for Successful School Based Management, Alexandria,Virginia : Association for Supervision and Curriculum Development, 1997.

[12] Fisher, D. L., \& Fraser, B. J, School Climate, (SET research information for teachers No.2), Melbourne: Australian Council for Educational Research, 1990.

[13] Creemers, B., Peters, T., \& Reynolds, D, School effectiveness and school improvement. Lisse, The Netherland: Swets \& Zeitlinger, 1989.

[14] Freiberg, H. J, Measuring school climate: Let me count the ways. Educational Leadership, 56(1), pp. 22-26,1998.

[15] Sweetland and Hoy (2000).

[16] Lipham, James. M. And Hoeh, James A. Jr, 1974 The Principalship : Foundations and Functions, New York : Harper and Row Publishers, 1974. 
[17] Caldwell, JB. And Spink, M.J, Learning the Self Managing School: Education Policy Perspectives. Washington D.C, USA: The Falmer Press, 1992.

[18] Santoso, Singgih, SPSS Versi 10 Statistic Data Analysis, Jakarta : PT Elex Media Komputindo Publishers, 2003.

[19] Borich, GD, Effective Taching Methodes, Columbus, Ohio : Merrill, 1988.

[20] Robbins, Stephen P, Organizational Behavior : Concepts, Controversions, and Aplications, Nine Edition. New Jersey : Prentice Hall Inc, 2001.

[21] Wadhwa, P, "The Relationship Between High Involvement Work Systems, Supervisory Support, and Organizational Effectiveness: The Role of Employee Experiences at Work". Disertasi. Kansas: University of Kansas, 2012.

[22] Heck, H.Ronald, Principals Instructonal Leadership and School Performance Implications for Policy Development, Educational Evaluation and Policy analysis Vol 14, N0.1 pp 21-34, University of Hawaii at Manoa, 2002.

[23] Steffen, Teresa, M. Nystrom, Paul C. Connor, Stephen, Satisfaction with Nursing Homes. Journal of Health Care Marketing. Vol. 16, 1996.

[24] Rodwell, John J. Rene Kienzle and Mark A. Shadur, The Relationship Among Work Related Perceptions Integral Role of Comunication, Human Resources Management Journal. Vol.37.3, 1998. 